\title{
ARTICLES
}

\author{
Submitted 05.22.2020. Approved 04.19.2021
}

Evaluated through a double-blind review process. Scientific Editor: Marcelo Vinhal Nepomuceno

Original version | DOI: http://dx.doi.org/10.1590/S0034-759020220103

\section{PSYCHOLOGICAL DISTANCE IN THE DIASPORA MARKETING OF NOSTALGIC PRODUCTS: A VENEZUELAN CASE}

\author{
Distância psicológica no marketing de produtos nostálgicos para comunidades em diáspora: 0 \\ caso venezuelano \\ Distancia psicológica en el marketing de productos nostálgicos para la diáspora: Caso venezolano
}

\begin{abstract}
Walter Palomino-Tamayo¹ | wpalomino@esan.edu.pe | ORCID: 0000-0002-1140-7362
Maria Christina Saksanian'1 | csaksanian@esan.edu.pe | ORCID: 0000-0003-1327-7554

Otto Regalado-Pezúa1 | oregalado@esan.edu.pe | ORCID: oooo-0oo1-6196-1479
\end{abstract}

1Universidad ESAN, Marketing Department, Lima, Peru

\begin{abstract}
With this first systematic review of specific literature about diaspora marketing, it was found that this emerging literature focuses mainly on opportunities related to trade, tourism, and the acculturation between countries with different languages in only one host country. This research contributes toward a greater understanding of diaspora buying behavior using the construal level theory, specifically regarding the purchase of nostalgic products and services, examining the case of Venezuelan diaspora in the broader international context of five host countries: Colombia, Peru, Chile, Ecuador, and Panama Another contribution is the use of e-WOM metrics derived from advertising posts on Instagram. The results show that diaspora consumers in host countries that have higher levels of individualism, less masculinity, and are further geographically from their homeland seek to consume greater amounts of nostalgic products.
\end{abstract}

KEYWORDS I Diaspora marketing, e-WOM, cultural dimensions, nostalgic products, construal level theory.

\section{RESUMO}

Esta primeira revisão sistemática da literatura sobre marketing de diáspora revela que os emergentes estudos têm por principal foco as oportunidades relacionadas ao comércio, turismo e a aculturação de pessoas em diáspora originárias de diversos países com idiomas diferentes em relação a apenas um país anfitrião. Esta pesquisa contribui para uma maior compreensão do comportamento de compra de comunidades em diáspora, especificamente em relação a produtos e serviços nostálgicos, usando a Teoria do Nível de Interpretação e considerando o caso da comunidade venezuelana em diáspora no contexto internacional mais amplo de cinco países anfitriões: Colômbia, Peru, Chile, Equador e Panamá. Outra contribuição do estudo é o uso de métricas e-WOM derivadas de postagens de publicidade no Instagram. Os resultados mostram que consumidores em diáspora vivendo em países com níveis mais elevados de individualismo, menor masculinidade e maior distância geográfica de sua terra natal, tendem a apresentar maior consumo de produtos nostálgicos.

PALAVRAS CHAVE I Marketing de diáspora, e-WOM, dimensões culturais, produtos nostálgicos, teoria do nível de interpretação.

\section{RESUMEN}

A través de esta primera revisión sistemática de la literatura específica del marketing de la diáspora, se encontró que ésta literatura emergente está enfocada en las oportunidades de comercio, turismo y aculturación entre personas de países con diferentes idiomas en un solo país anfitrión. Esta investigación contribuye a comprender el comportamiento de compra de la diáspora, específicamente con respecto a productos y servicios nostálgicos, en un contexto internacional más amplio considerando cinco países anfitriones: Colombia, Perú, Chile, Ecuadory Panamá, y utilizando la teoría del nivel de conceptualización. Otra contribución es la utilización de las métricas e-WOM derivadas de publicaciones publicitarias en Instagram. Los resultados muestran que los consumidores de la diáspora de los países anfitriones con una mayor cultura individualista, una menor masculinidad y una mayor distancia geográfica de su tierra natal prefieren el consumo de productos nostálgicos.

PALABRAS CLAVE I Marketing de la diáspora, e-WOM, dimensiones culturales, productos nostálgicos, teoría del nivel de conceptualización. 


\section{INTRODUCTION}

The flow of people between different countries is an age-old phenomenon that has attracted global attention due to the tremendous increase in the number of people moving from their home countries to settle in a host nation. In the last three decades or so, the world has witnessed an unprecedented movement of people. Statistics on global migration show that in 2018, 258 million people were residing in a country other than their country of birth, an increase of $49.1 \%$ compared to 2000 , and $153 \%$ compared to 1980 (Vidal \& Tjaden, 2018). This phenomenon, known as "diaspora," is defined by Safran (as cited in Tambiah, 2017, p. 169) as "expatriate minority communities that keep nostalgia or fantasy about their homeland."

The term "diaspora,", was first used around 250 BC when the Hebrew Bible was translated into Greek. This translation, the Septuagint, used the verb diaspeirein and the noun diasporá to refer to the condition of spiritual agony accompanying the banishment of the Jews by an angry God. Currently, several different terms, such as

"immigrant," "ethnic community," “refugee," “exile," and "overseas community," share the same rough meaning (Tambiah, 2017).

Since 2014, Venezuela has been experiencing a massive wave of emigration. As of April 2019, more than 1.2 million Venezuelans were living in Colombia and 728,000 in Peru, the two largest diaspora concentrations in the region, followed by Chile, Ecuador, and Panama with 288,000, 263,000, and 94,000 Venezuelans, respectively (R4V, 2019). This scenario, the largest migratory exodus in Latin American (LA) history, is an opportunity to undertake research into diaspora marketing.

Legal and political restrictions have surrounded the Venezuelan exodus. In 2015, neither visas nor passports were required for these migrants thanks to regional integration agreements (the Andean Community and Mercosur). This situation changed in August 2017, however, when Venezuela was suspended from Mercosur and lost immigration benefits. Specifically, the member countries of these regional communities accused the Venezuelan government of having violated the "democratic clause" of the agreement (R4V, 2019), and from that moment on each country determined its own immigration policy. In October 2017, Panama was the first country to request that Venezuelans present a passport and visa upon entry. Peru, Chile, and Ecuador implemented passport and visa requirements in 2019. Colombia allowed only temporary entry permits, always with a passport. But Venezuelans report that obtaining a Venezuelan passport is difficult due to the high cost and bureaucracy. Before 2017, most Venezuelan immigrants entered these countries illegally, so Colombia, Peru, and Ecuador implemented regularization policies with temporary permits that allowed Venezuelans to work and obtain access to healthcare and primary education for children. Current policies discourage legal migration, and a humanitarian visa is the only legal route available to Venezuelans, but many humanitarian visa requests are not being granted (R4V, 2019).

Nevertheless, over 5 million Venezuelans live abroad (R4V, 2019), and understanding how these diasporas fulfill their needs is essential. Unfortunately, systematic literature review results on diaspora marketing show that relevant studies are mostly qualitative and descriptive; only $23 \%$ of the selected articles are quantitative with some theoretical support. Some studies aim to explain the impacts of diasporas from an economic perspective, such as the enhancement of trade opportunities between countries due to the advantage migrants have of knowing the needs of both countries (Artal-Tur, Ghoneim, \& Peridy, 2015; Kumar \& Steenkamp, 2013; Tien \& Luan, 2015). Other studies focus on the tourism opportunities involved in taking migrants back to visit their homeland (Morgan, Pritchard, \& Pride, 2003; Murdy, Alexander, \& Bryce, 2018; Weaver, Kwek, \& Wang, 2017; Yousaf \& Samreen, 2016). 
This study, which focuses on the Venezuelan case, aims to explain how the psychological distance created by the different social, spatial, and time contexts (that are specifically cultural differences) of the home and host countries of a diaspora leads to the consumption of nostalgic products. "Nostalgia" is described as "a sentimental longing or a wistful affection for a period in the past” (Oxford Dictionary, n.d.).

This research makes three contributions to the emerging literature on diaspora marketing. First, a detailed literature review of diaspora marketing, the first literature review on this topic, was undertaken to distinguish this perspective from that of other disciplines that also study diasporas. Second, the Construal Level Theory (CLT) (Liberman, Trope, \& Wakslak, 2007) is extended to a new domain to help explain the behavior of diaspora consumers in a broad, international context. Focusing on five host countries was innovative, as prior studies focused on only one, which means that theoretical external validity has been extended. Third, this study uses e-WOM metrics to confirm hypotheses about diaspora consumers' search for nostalgic products. The following section presents a literature review undertaken to summarize the most commonly studied themes of diaspora marketing.

\section{LITERATURE REVIEW}

This literature review aims to analyze the literature on diaspora marketing specifically, not with regard to diaspora in general. To focus on the domain target, a systematic search was carried out to identify relevant articles published on the subject, and therefore the major bibliographic databases and search engines, like WoS, EBSCOhost, Science Direct, Emerald, JSTOR, and SpringerLink, were consulted. Only articles published in the fields of communications, hospitality, leisure, sports, tourism, economics, management, and business were selected. After reading the articles to make sure they fit into the diaspora marketing domain, the final review comprised 35 articles (Exhibit 1). This literature review helped this study target the main research topics in diaspora marketing. It also helped identify the evolution of diaspora marketing, relevant theories, conceptual perspectives, and the methodologies used, and it helped to confirm the gap in the literature that this article addresses.

\section{Exhibit 1. Representative research in diaspora marketing organized by year}

\begin{tabular}{l|c|c|c}
\hline Author(s) & Methodology & Theoretical/ Conceptual Perspective & Home and host countries \\
\hline $\begin{array}{l}\text { Quinn and } \\
\text { Devasagayam } \\
(2005)\end{array}$ & Quantitative & $\begin{array}{c}\text { Acculturation and self-identified } \\
\text { ethnicity }\end{array}$ & Indian diasporas in the USA \\
\hline Frank et al. (2012) & Quantitative & Customer Satisfaction Index structure & Chinese diasporas in Japan \\
\hline $\begin{array}{l}\text { Kumar and } \\
\text { Steenkamp (2013) }\end{array}$ & Qualitative & Acculturation Theory & Indian diasporas in the USA \\
\hline Holak (2014) & Qualitative & $\begin{array}{c}\text { Nostalgia approach and sociological, } \\
\text { historical, and cross-cultural } \\
\text { perspectives }\end{array}$ & $\begin{array}{r}\text { Russian diaspora in New York, USA } \\
\text { Cross and Gilly } \\
\text { (2014) }\end{array}$ \\
\hline
\end{tabular}




\begin{tabular}{|c|c|c|c|}
\hline Author(s) & Methodology & Theoretical/ Conceptual Perspective & Home and host countries \\
\hline $\begin{array}{l}\text { Demangeot et al. } \\
\text { (2015) }\end{array}$ & Qualitative & Acculturation Theory & -- \\
\hline $\begin{array}{l}\text { Artal-Tur et al. } \\
(2015)\end{array}$ & Quantitative & $\begin{array}{l}\text { Network approach in trade-migration } \\
\text { relationship }\end{array}$ & Egyptian diasporas in France \\
\hline $\begin{array}{l}\text { Badinella and } \\
\text { Chong (2015) }\end{array}$ & Qualitative & $\begin{array}{l}\text { Economic sociology, social } \\
\text { embeddedness, and social relations }\end{array}$ & $\begin{array}{c}\text { Black African diasporas in London, the } \\
\text { UK }\end{array}$ \\
\hline Brillon (2015) & Qualitative & Political economy & $\begin{array}{l}\text { Filipino diasporas worldwide and in the } \\
\text { Philippines }\end{array}$ \\
\hline $\begin{array}{l}\text { Tien and Luan } \\
(2015)\end{array}$ & Quantitative & International trade theories & Chinese diasporas in Taiwan \\
\hline $\begin{array}{l}\text { Chandrasen } \\
(2016)\end{array}$ & Quantitative & Acculturation Theory & International students in the UK \\
\hline $\begin{array}{l}\text { Kim and Chen } \\
(2016)\end{array}$ & Qualitative & Acculturation Theory & Asian diasporas in the USA \\
\hline $\begin{array}{l}\text { Yousaf and } \\
\text { Samreen (2016) }\end{array}$ & Quantitative & Country Brand Perspective & $\begin{array}{l}\text { Pakistani diasporas in Chinese and } \\
\text { Malaysian universities }\end{array}$ \\
\hline Dey et al. (2017) & Qualitative & Acculturation Theory & Asian diasporas in the UK \\
\hline $\begin{array}{l}\text { Guzmán et al. } \\
(2017)\end{array}$ & Quantitative & Self-concepts & $\begin{array}{c}\text { Mexicans in Mexico City and Mexican } \\
\text { diasporas in the Dallas/Fort Worth, USA } \\
\text { metro area }\end{array}$ \\
\hline $\begin{array}{l}\text { Papadopoulos et } \\
\text { al. (2017) }\end{array}$ & Quantitative & $\begin{array}{c}\text { Product-Country Image and Animosity } \\
\text { Theory }\end{array}$ & Egyptian diasporas in Canada \\
\hline $\begin{array}{l}\text { Weaver et al. } \\
(2017)\end{array}$ & Qualitative & $\begin{array}{l}\text { Cognitive, affective, and conative } \\
\text { reactions }\end{array}$ & $\begin{array}{l}\text { Tourists of Chinese ethnic origin in } \\
\text { mainland China }\end{array}$ \\
\hline $\begin{array}{l}\text { Henthorne et al. } \\
(2018)\end{array}$ & Quantitative & Social identification theory & $\begin{array}{l}\text { People of African descent in South } \\
\text { Africa, Brazil, and the USA }\end{array}$ \\
\hline Zhao et al. (2018) & Quantitative & Cultural effects & Chinese-American consumers \\
\hline Dey et al. (2019) & Qualitative & Acculturation Theory & Ethnic consumers in London, the UK \\
\hline
\end{tabular}

The concept of diaspora marketing is recent and emerging: academic interest in diaspora marketing had grown slowly until four years ago, after which $71 \%$ of the articles were published. Of the papers selected, $54 \%$ are qualitative, $43 \%$ are quantitative, and $3 \%$ used mixed methods. Moreover, $56 \%$ use theoretical support: $20 \%$ Acculturation Theory, $11 \%$ economic theories, $11 \%$ country and cultural theories, $6 \%$ psychological theories, and $6 \%$ sociological theories, while the remaining $44 \%$ are descriptive and empirical without any theoretical support.

One of the theoretical approaches used in this domain is Acculturation Theory (AT) and the consumer acculturation process (Penaloza, 1994). Brown (1980) suggested that the diaspora acculturation process comprises four stages. Kumar and Steenkamp (2013) segmented diaspora consumers to help emerging market companies build international brands. Demangeot, Broderick and Craig (2015) explained the process of multicultural adaptation in geographic marketplaces. Based on the level of acculturation, Kim and Chen (2016) explained the diaspora's response to localized or de-ethnicized product strategies. Dey, Balmer, Pandit, Saren and Binsardi (2017) explained the diaspora's dual acculturation process of adoption and integration. Dey et al. (2019) also conceptualized how consumption of ethnic products affects a diaspora's acculturation. Quinn and Devasagayam (2005) adapted and validated the Suinn-Lew ethnicity scale from social psychology to measure diaspora acculturation. 
Studies based on economic theories, on the other hand, mostly tried to explain how networks of migrants help homeland businesses (Brillon, 2015; Artal-Tur et al., 2015; Tien \& Luan, 2015). Badinella and Chong (2015) used economic sociology, social embeddedness, and social relations to study black diaspora esthetic practices in the art market. Frank, Abulaiti and Enkawa (2012) explored differences in customer satisfaction, repurchase intent, and word-of-mouth intent between Chinese-born and locally born consumers in Japan. Yousaf and Samreen (2016) studied the influence of the media on Pakistani brand reputation. Most recently, Papadopoulos, Banna and Murphy (2017) evaluated the effect of affinity, animosity, and images of the homeland on purchase intentions.

From a sociological standpoint, Henthorne, Williams and George (2018) examined the African diaspora's complaining behavior based on the Social Identification Theory. Holak (2014) studied nostalgic evocation through traditional Russian cuisine. Finally, empirical and descriptive papers were dedicated to studying diaspora tourism (Murdy et al., 2018), the international penetration of products by way of diaspora networks (Bundas, 2018), diaspora consumer behavior (Morgan et al., 2003), food (Mostafa, 2018), consumer acculturation and retailing (Bundy, 2017), and damage to diaspora image caused by bad press (Ogunyemi, 2018).

Regardless of the theoretical foundation used to study diaspora behaviors, cultural factors seem to be a key element. To illustrate the effect of cultural factors, Cross and Gilly (2014) found that families with bicultural immigrant spouses engaged with the host culture faster than monocultural families. Another study based on Hofstede's cultural dimensions showed the influence of cultural gender roles (Zhao, Sun, Devasagayam, \& Clendenen, 2018). Similarly, Guzmán, Paswan and Fabrize (2017) showed that brand perception is different for Latinos residing in their home country than for immigrants because of cultural differences. Weaver et al. (2017) found that Chinese diaspora members have a higher degree of cultural connectedness with China.

Since the systematic literature review was concluded, other papers have been recently published, but they do not change the conclusions of the review. These papers focused on the influence of diaspora networks on product diffusion (Elo, Minto-Coy, Silva, \& Zhang, 2020; Matejowsky, 2020), and how levels of diaspora acculturation are related to leisure travel motivations and desired experiences in the motherland (Preez \& Govender, 2020).

This review shows that diaspora marketing literature focuses primarily on explaining business impacts, drivers, and opportunities, and attaches little importance to understanding the diaspora's purchase of nostalgic products. This is a gap in the literature.

Another important topic to review is word of mouth (WOM), which is the way consumers share information about goods, services, brands, or companies with other consumers. Electronic word of mouth (e-WOM) refers to when this information is shared on the Internet (for example, via likes, reviews, comments, tweets, blog posts, etc.) (Rosario, Sotgiu, Valck, \& Bijmolt, 2016). Evidence of the positive relationship between e-WOM and sales is abundant (see Rosario et al., 2016), and for this reason, measuring e-WOM is a valid way of estimating purchase behavior. eWOM includes non-textual communication, such as "liking" or "re-tweeting", as well as comments. It can be defined as a potential or actual client's positive or negative assessments of an ad, brand, or company. Moreover, an Instagram user, instead of writing a comment or sharing a post, can click the "like" button as a quick way of showing their approval, because Instagram's primary interaction and communication method is through images and likes. The literature on internet communication considers liking and commenting on a post to be e-WoM, because when liking or commenting a user expresses a public opinion (Vries, Gensler, \& Leeflang, 2012). Specifically, Rosario et al. (2016), in their meta-analysis, found that the number of e-WOM likes is more powerful for affecting sales than any other qualification metric, either positive or negative (valence). 


\section{THEORETICAL BACKGROUND AND HYPOTHESIS DEVELOPMENT}

Different theoretical frameworks were used to explain diaspora marketing, and they mostly focused on AT and theories from economics, psychology, and sociology. These studies (Table 1), however, were mainly carried out in contexts with significant language barriers and a huge cultural distance between the host and home countries (Chandrasen, 2016; Dey et al., 2017, 2019; Kim \& Chen, 2016), The context of the Venezuelan case is different: specifically, there is no language barrier, since Spanish is the official language in all the studied countries. Neither are these countries experiencing military or religious conflicts, which are conditions that usually generate brand animosity (Papadopoulos et al., 2017). Theoretically, AT is used to describe the diaspora's process of adaptation and assimilation into the host country's culture (Brown, 1980). The purchase of nostalgic products indicates the opposite phenomenon: the diaspora's culture of origin is being affirmed, signaling the lack of an acculturation process. De-Juan-Vigaray, Garau-Vadell, and Sesé (2021) found a relationship between the length of residence and acculturation and, subsequently, shopping acculturation, which refers to the level of attachment to businesses associated with one's ethnic origin. In this case, the shorter the length of residence, the less the Venezuelan diaspora should be acculturated; this would mean less shopping acculturation to the host country, and maintenance of an attachment to the home country. Consequently, AT describes only the diaspora's adaptation process and does not possess the mechanisms for explaining a preference for nostalgic products, which the CLT does (Heinberg, Katsikeas, Ozkaya, \& Taube, 2019).

Table 1. Research on diaspora marketing using acculturation theories

\begin{tabular}{l|l|c|l}
\hline Host / Home country & Language & $\begin{array}{c}\text { Cultural Distance } \\
\text { (Kogut \& Singh, 1988) }\end{array}$ & Authors \\
\hline USA/India & English/Hindi & 75.4 & Quinn and Devasagayam (2005) \\
\hline Japan/China & Japanese/Mandarin & 79.8 & Frank et al. (2012) \\
\hline England/Nigeria & English/Hausa & 87.2 & Badinella and Chong (2015) \\
\hline France/Egypt & French/Modern Standard Arabic & 85.0 & Badinella and Chong (2015) \\
\hline USA/China & English/Mandarin & 112.1 & Kim and Chen (2016) \\
\hline USA/Philippines & English/Tagalog \& English & 84.2 & Kim and Chen (2016) \\
\hline USA/Mexico & English/Spanish & 87.1 & Guzmán et al. (2017) \\
\hline Canada/Egypt & $\begin{array}{l}\text { English \& French/Modern } \\
\text { Standard Arabic }\end{array}$ & 100.0 & Papadopoulos et al. (2017) \\
\hline England/China & English/Mandarin & 100.7 & Dey et al. (2019) \\
\hline
\end{tabular}

Note: The calculation of Cultural Distance was made using the indicators of Hofstede (2019)

For this reason, the present study uses the CLT as its framework (Liberman et al., 2007), which helps explain how people think of "distant" events and why they prefer nostalgic brands and products, which are associated with socially, spatially, and temporally distant events (Heinberg et al., 2019).

According to the CLT, construal is an interpretation of events. To represent "near" events, individuals use concrete, low-level construal, unstructured, incidental features, and rich details. In contrast, to represent distant events individuals use high-level construal abstraction and schematic, decontextualized representations, omitting secondary and incidental features (Trope, Liberman, \& Wakslak, 2007). It has been found that there exists a 
relationship between psychological distance and abstraction, specifically temporal difference in abstraction, and this provides evidence of the relationship between construal and the dimensions of spatial distance, social distance, and the probability that an event will occur (Trope et al., 2007). Specifically, interpersonal similarity is a form of social distance: previous studies have found similar people are perceived as being socially closer to oneself than dissimilar ones, who are associated with social distance (Liviatan, Trope, \& Liberman, 2008).

Venezuelan diasporas are socially, spatially, and temporally distant from their homeland. The absence of relatives and friends leads to social distance. The fact that they are far from their homeland indicates spatial distance, and the fact that time has passed since their childhood leads to temporal distance. In turn, distance can evoke a longing for diaspora homeland brands, products, services, and forms of entertainment.

The CLT states that psychological distance changes people's mental representations of events (Liviatan et al., 2008). Differences in cultural dimensions are a form of social distance. The more similar someone is to others, the more socially near they seem. The opposite is when people in one social group feel they cannot relate to another group; in this case, a diaspora would perceive a greater psychological distance from people both in their homeland and their host country (Liviatan et al., 2008).

Hofstede (2019) defines culture "as the collective mental programming of the human mind which distinguishes one group of people from another” (p. 6), meaning that cultural differences between a diaspora's homeland and the host country should create social distance, as indicated by the CLT. The three psychological distances: social, spatial, and temporal, are associated with the decision to purchase nostalgic products (Heinberg et al., 2019). Emotional brand attachment refers to the affective connection consumers form with brands, and this corresponds to the social aspect of the CLT (Heinberg et al., 2019). As a result, social distance is associated with a preference to consume nostalgic products (Heinberg et al., 2019).

The cultural dimension differences between the homeland and the host country also create a social distance for diasporas that leads to a preference to consume nostalgic products. Social distance results when the host country possesses a higher level of individualism than the diaspora homeland, because in collectivist societies people belong to tightly-knit in-groups that take care of them in exchange for loyalty, while in individualistic societies people are supposed to look after themselves (Hofstede, 2019). This can make a diaspora uncomfortable due to greater social distance, which, in turn, leads to a preference for nostalgic products. Furthermore, there is evidence that collectivist countries (like Venezuela) prefer hedonic products (Talay, Akdeniz, Obal, \& Townsend, 2019) and local brands (Krautz \& Hoffmann, 2017). Consequently, the following hypothesis is posited:

H1: In host countries where individualism is higher than in the homeland, diasporas' purchases of nostalgic products are greater than they are in host countries where individualism is equal to that of the homeland.

Likewise, when there is a difference between the diaspora's homeland and the host country in terms of the cultural dimension of masculinity, increased social distance may be felt. High levels of masculinity indicate that a society is driven by competition, achievement, and success, while high levels of femininity mean that the dominant value in society is caring for others, that quality of life is an important sign of success, and that standing out from the crowd is not admirable (Hofstede, 2019). We suggest that diasporas from countries that are high in masculinity living in a feminine country might tend to consume products from their homeland as a sign of success. For people from a masculine country like Venezuela, success and recognition are an inherent part of societal norms (Hofstede, 2019). For masculine groups, buying expensive products and the latest fashions in different specialty stores is a way of showing success and status (Kumar \& Pansari, 2016). Nostalgic evocation through 
traditional homeland cuisine can establish a social connection (Holak, 2014), so buying nostalgic products will signal success because they are imported and expensive, and the consumption of foreign products is a proxy for success (Talay, Townsend, \& Yeniyurt, 2015). Hence, the following hypothesis is posited:

$\mathrm{H}_{2}$ : In host countries where masculinity is lower than in the homeland, diasporas' purchases of nostalgic products are greater than they are in host countries with masculinity equal to that of the homeland.

Newcomers still need to find ways to generate enough income to attend to their basic needs, such as food, housing, healthcare, and education. Despite their common Spanish heritage, Latin American countries have different levels of economic development (Vassolo, Castro, \& Gomez-Mejia, 2011).

A country's economic development (ED) influences all its economic agents. Lower ED means firms will have fewer clients, fewer distribution channels, less infrastructure, fewer business opportunities, and higher risks that influence the decisions taken by Latin American people (Palomino-Tamayo, Timana, \& Cerviño, 2020). A country's ED also influences consumer brand decisions and brand performance (Talay et al., 2015). Lower economic development in Latin American countries is characterized by a lack of employment and increased difficulty in finding work, and people then resort to informal jobs to survive (Vassolo et al., 2011). This lower ED context creates personal economic hardship, sparks animosity toward buying foreign products (host country products) and results in a preference for group-related products (Leonidou, Kvasova, Christodoulides, \& Tokar, 2019). This animosity consequently creates a social distance of belongingness among Venezuelan diasporas, which leads to a preference to consume nostalgic products, as CLT predicts. Thus, the following hypothesis is posited:

H3: In host countries with lesser (greater) economic development than the homeland, diasporas' purchases of nostalgic products are greater (less) than they are in those host countries in which economic development is higher (lower) than in the homeland.

Geographic proximity lowers transportation and communication costs and facilitates personal interaction, the exchange of information, and international trade (Ghemawat, 2001). Greater geographic distance between the home and the host country increases spatial distance, which distorts perceptions (Choi \& Yeniyurt, 2015), causing a feeling of homesickness, which members of the diaspora try to assuage by consuming nostalgic products (Heinberg et al., 2019). Therefore, diasporas in countries that are geographically distant from their homeland tend to seek to consume nostalgic products to a greater degree. Consequently, the following hypothesis is posited:

$\mathrm{H}_{4}$ : In host countries at a greater geographic distance from the homeland, diasporas' purchases of nostalgic products are greater than they are in geographically less distant host countries.

\section{METHODOLOGY}

\section{Data source and sample}

On social media platforms like Facebook, Twitter, and Instagram, users can follow other users, comment on their posts, and track the "likes" and comments their own posts receive. While Facebook and Twitter do incorporate images, users also rely heavily on text, shared posts, and other types of non-imaged interactions. Images dominate on Instagram, however, and its users rely on "likes" as the primary means of interaction and communication (Schmeichel, Kerr, \& Linder, 2020). 
Instagram's exclusive focus on images differentiates it from other platforms and is the reason Instagram was chosen as the data source for this research. The use of photographs and images means that one of the frequently recurring subjects is the relationship between Instagram and nostalgia. Several authors attribute this relationship between Instagram and nostalgia to the esthetics of Instagram's filters, which can easily reproduce a combination of film textures, framing formats, tones, patinas, and vintage effects, including warm colors and the square format of Kodak and Polaroid cameras, color tinting, and border formats reminiscent of analog technology (Wagner, 2018). In summary, Instagram is the most suitable platform for studying nostalgia.

Equally important, and in contrast to Facebook, it is common for users on Instagram to follow, view, like, and comment on photos of people they do not know personally. But the number of strangers followed and higher posting frequency are associated with depression (Reece \& Danforth, 2017), and due to the acculturation processes that diasporas experience, depression is common among them (Brown, 1980). Instagram's association with depression makes it an appropriate data source for this study.

Many people in the Venezuelan diaspora on Instagram often look for information about immigration status and view Venezuelan-oriented advertising (see Table 2). The Instagram profiles shown in Table 2 were selected because they have the largest number of followers in each host country and have advertising posts that can be analyzed.

Table 2. Online Venezuelan diaspora communities by country

\begin{tabular}{l|l|c|l}
\hline COUNTRY & INSTAGRAM SOCIAL NETWORK & FOLLOWERS & LINK \\
\hline COLOMBIA & Tu Pana en Colombia & $72.2 \mathrm{k}$ & $\underline{\text { https://www.instagram.com/tupanaencolombia/ }}$ \\
\hline PERU & Peruzuela & $150 \mathrm{k}$ & $\underline{\text { https://www.instagram.com/peruzuela/?hl=es-la }}$ \\
\hline CHILE & Venezolanos en Chile & $411 \mathrm{k}$ & $\underline{\mathrm{https}: / / \mathrm{www} . \text { instagram.com/venezolanosenchile/ }}$ \\
\hline ECUADOR & Venezolanos En Ecuador & $21.8 \mathrm{k}$ & $\mathrm{https://www.instagram.com/venezolanosenecuadoroficial/?hl=es-la}$ \\
\hline PANAMA & Panazolanos & $39.7 \mathrm{k}$ & $\mathrm{https://www.instagram.com/panazolanos/?hl=es-la}$ \\
\hline
\end{tabular}

\section{Measurements}

As explained in the literature review, e-WOM likes are a powerful metric affecting sales (Rosario et al., 2016). Thus, this study considers the number of likes of advertising posts to be a measure of e-WOM among online Venezuelan Instagram communities in Colombia, Peru, Chile, Ecuador, and Panama.

Hofstede's indices were used (Hofstede, 2019) for measuring cultural dimensions. To classify each host country using the masculinity/femininity and individualism dimensions, cultural distance (CD) was used (Kogut \& Singh, 1988). In this case, it was only used for classification purposes, with only one dimension per grouping. The CD between the host country and Venezuela shows if the country is higher or lower than Venezuela in the cultural dimension. Hofstede's cultural model was used in this research because it is appropriate at the country level, according to the seminal author. Schwartz's model is defined for the individual level, which is not the case in this study (for further discussion, see Fischer, Vauclair, Fontaine, \& Schwartz, 2010).

To measure economic development distance, the percentage difference in the 2018 GDP per capita between Venezuela and the host country was used (Palomino-Tamayo et al., 2020). The source of the GDP per capita information was the central bank of each country. 
Finally, to measure geographic distance, the distance between the capital city of Venezuela and the capital city of the host country was used, in terms of their geographic coordinates as recorded in the GeoDist database, CEPII (2019).

A total sample was obtained of 44 advertising posts in Colombia, 40 in Peru, 40 in Chile, 84 in Ecuador, and 50 in Panama, from a search run from May to October 2019. The final sample was 258 ads, which received 30,785 e-WOMs (averaging 119 e-WOMs per ad). Two researchers reviewed all of the advertising posts and classified them into ten different categories. The researchers were marketing professors with knowledge of advertising. They were not otherwise involved in this study and in order to avoid bias they had no previous information about the study's title, objectives, or hypotheses. Ads were easily classified because of the graphic nature of Instagram ads and the directness of the accompanying text. The researchers and authors defined the category names and consolidated all services into only one category, "services related to Venezuela," because of the broad types of service found. One of the researchers divided the "help wanted" category into two sub-categories: "specialized help wanted" and "general help wanted." In other words, after agreeing on the category names, the second researcher split the first researcher's single category into two sub-categories. The main difference between the researchers' classification was the names they assigned to the categories, but because they were very similar, it was not hard to come to an agreement in the end.

A second review was then conducted to categorize the ads as either "nostalgic" or "economic". When the authors disagreed on the classification, they reviewed the ad in order to come to an agreement. The nostalgic products and services related to the homeland that were the main focus of the study included Venezuelan food (arepas, tamales, chocolates, ham bread, etc.), Venezuelan entertainment (parties or concerts with Venezuelan music and artists), services related to Venezuela (services for sending gifts and medicine to parents in Venezuela, food importation, and air or bus tickets from the host country to Venezuela), and money transfer (due to the Venezuelan government's restrictions, these services offered to send remittances to relatives in Venezuelan currency). Economic products included help wanted ads (ads placed by employment agencies; ads for job fairs targeting Venezuelans; and general help wanted ads for manual labor, sales, and administrative positions that did not require any previous training), specialized help wanted ads (help wanted ads looking for technicians and professionals, such as electricians, barbers, bakers, and engineers with some degree of specialization and experience), ads for educational opportunities (technical courses or programs to obtain host country certifications), ads for basic consumer products (computers, mobile phones, over-the-counter medicines), and ads for financial services (mortgages and loans for vehicle purchases).

\section{RESULTS}

Three of the ten identified advertising categories received the majority of the likes: Venezuelan entertainment, Venezuelan food, and help wanted ads, but varied somewhat depending on the host country. Table 3 displays the e-WOM descriptive statistics for each ad category and summarizes the e-WOM behavior of the Venezuelan diaspora. Ads for Venezuelan entertainment generated the most e-WOM in Peru, mean=255(SD=252) and Ecuador, mean=124 $(S D=159)$. They were also important in Panama, mean=13(SD=7), Colombia, mean=104 $(S D=66)$, and Chile, mean=309(SD=141). The help wanted ads were the most important in Colombia, mean=204(SD=78), the second most important in Chile, mean $=433(S D=162)$, and somewhat relevant in Ecuador, mean $=57(S D=35)$ and Panama, mean $=6(S D=7)$. Another category that generated high e-WOM across all countries was Venezuelan food, especially in Colombia, mean=149(SD=39), Peru, mean=118(SD=68), Ecuador, mean=92(SD=73), and Panama, 
mean=12 $(S D=10)$. There were some exceptional cases: in Panama, ads for education generated the most e-WOM, mean $=15(S D=2)$, while in Chile, financial services generated the most e-WOM, mean=804(SD=478).

Table 3. Descriptive e-WOM statistics by country and advertising category

\begin{tabular}{|c|c|c|c|c|}
\hline & MEAN & STD. DEV. & MIN & MAX \\
\hline \multicolumn{5}{|l|}{ COLOMBIA } \\
\hline Help Wanted & 204 & 78 & 110 & 315 \\
\hline Venezuelan Food & 148 & 59 & 65 & 226 \\
\hline Venezuelan Entertainment & 104 & 66 & 51 & 178 \\
\hline Work Consulting & 44 & 14 & 28 & 70 \\
\hline Services Related to Venezuela & 36 & 11 & 20 & 43 \\
\hline Money Transfer & 29 & 12 & 13 & 49 \\
\hline \multicolumn{5}{|l|}{ PERU } \\
\hline Venezuelan Entertainment & 255 & 252 & 24 & 602 \\
\hline Education & 142 & 133 & 32 & 517 \\
\hline Cellular Phone Gift & 121 & 93 & 39 & 362 \\
\hline Venezuelan Food & 117 & 68 & 41 & 173 \\
\hline Services Related to Venezuela & 91 & 49 & 18 & 146 \\
\hline \multicolumn{5}{|l|}{ CHILE } \\
\hline Financial Services & 804 & 478 & 294 & 1243 \\
\hline Help Wanted & 433 & 162 & 194 & 643 \\
\hline Venezuelan Entertainment & 309 & 141 & 134 & 593 \\
\hline Services Related to Venezuela & 187 & 81 & 29 & 274 \\
\hline Specialized Work & 145 & 57 & 76 & 238 \\
\hline \multicolumn{5}{|l|}{ ECUADOR } \\
\hline Venezuelan Entertainment & 124 & 159 & 23 & 855 \\
\hline Services Related to Venezuela & 94 & 72 & 15 & 258 \\
\hline Venezuelan Food & 92 & 73 & 30 & 236 \\
\hline Education & 58 & 52 & 4 & 195 \\
\hline Help Wanted & 57 & 35 & 2 & 114 \\
\hline Specialized Work & 46 & 15 & 30 & 66 \\
\hline Money Transfer & 30 & 2 & 32 & 119 \\
\hline \multicolumn{5}{|l|}{ PANAMA } \\
\hline Education & 15 & 2 & 13 & 17 \\
\hline Venezuelan Entertainment & 13 & 7 & 7 & 20 \\
\hline Venezuelan Food & 12 & 10 & 2 & 22 \\
\hline Help Wanted & 6 & 7 & 1 & 24 \\
\hline Basic Consumer Products & 5 & 3 & 2 & 12 \\
\hline Services Related to Venezuela & 4 & 3 & 1 & 12 \\
\hline
\end{tabular}


To test the hypotheses, an ANOVA and Welch's t-test were conducted, in which the dependent variable for each group of host countries was the e-WOM of the ads. First, the host countries were classified (using \% CD difference) as having higher individualism than Venezuela (Peru $C D=+33 \%$ and Chile $C D=+92 \%$ ), or individualism of a similar level to that of Venezuela (Colombia $C D=+8$, Ecuador $C D=-33 \%$, and Panama $C D=-8 \%$ ). The results indicate differences between the groups that are consistent with $\mathrm{H}_{1}$ : countries with higher individualism than Venezuela, mean 205(SD=38.8), have greater e-WOM than countries with equal individualism, mean=74(SD=9.7) (see Figure 1-A). The difference is significant and positive (Mdiff=131, SDdiff=39.9, Welch's DF=39.7, $t=-3.27, p<.01$ ) and supports Hypothesis $\mathrm{H}_{1}$. As a robustness check, the estimation was run without Ecuador. The results indicated that the other countries still had about the same level of individualism (mean=43, SD=57). The difference remained significant and positive (Mdiff=162, Welch's DF=38.1, $t=-4.099, p<.0001$ ); therefore, the results remain valid.

Second, host countries were classified (using \% CD difference) as being lower in the masculinity dimension (Peru $=-42 \%$, Chile $=-62 \%$, and Panama $=-40 \%$ ), or similar in masculinity to Venezuela (Colombia $C D=-12 \%$ and Ecuador $C D=-14 \%$ ). Here, too, there are differences in the results (Figure 1-B) between countries with lower masculinity than Venezuela, mean $=118(S D=16.2)$, which have greater e-WOM, and countries with equal masculinity, mean $=67(S D=11.4)$. In the same way, the difference is significant and positive (Mdiff=51, SDdiff=19.1, Welch's $\mathrm{DF}=133.2, \mathrm{t}=2.59, \mathrm{p}(.01)$, in agreement with Hypothesis $\mathrm{H} 2$.

Third, to test $\mathrm{H}_{3}$, host countries were classified as countries with a higher economic development distance than Venezuela (Chile and Panama) or a lower economic development distance than Venezuela (Peru, Colombia, and Ecuador). In this case, there were very slight differences in the results (Figure $1-C$ ). Host countries with a higher economic development distance, mean=131 $(S D=45.4)$, have e-WOM values similar to those of countries with a lower economic development distance, mean $=100(S D=10.6)$. In this case, the difference is not significant (Mdiff=31, SDdiff=46.6, Welch's DF=-34.6, $\mathrm{t}=-0.65, \mathrm{p}=.74$ ), and so Hypothesis $\mathrm{H}_{3}$ is not supported.

Fourth, host countries were classified by their geographic distance from the homeland. Colombia and Panama were less geographically distant from Venezuela, while Ecuador, Peru, and Chile were more geographically distant. Host countries at a greater geographic distance, mean=144( $S D=18.9)$, had higher e-WOM values (see Figure 1-D) than host countries that were closer, mean $=43(S D=7)$. The difference was significant and positive (Mdiff=101, SDdiff=20.5, Welch's DF=118.7, $t=4.92, p<.001$ ), so Hypothesis $\mathrm{H}_{4}$ is supported.

Finally, the ATE of the population was estimated (Table 4) based on a direct comparison between treatment and control diaspora groups that received different levels of observationally matched treatment; such a comparison can be interpreted causally (Imbens \& Rubin, 2015). First, the treatment effect for diaspora groups in countries with high individualism was estimated using the e-WOM metric, and masculinity, economic development distance, and geographic distance were used as co-variables. The result shows a significant and positive treatment effect for host countries with high individualism ( $A T E=70, z=2.62, p=.009$ ). Then, when the group of host countries with lower levels of masculinity was placed in the treatment group and the equally masculine host countries were kept as the control group, with individualism, economic development distance and geographic distance as co-variables, there was a significant and positive effect for countries with low levels of masculinity $(A T E=48, z=2.58, p=.010)$. Similarly, when geographic distance was the treated variable and masculinity and economic development distance were co-variables, a significant and positive effect was found for the diaspora group in a geographically more distant country (ATE=114, z=4.04, p<.001). These results are in harmony with Hypotheses $\mathrm{H}_{1}, \mathrm{H}_{2}$, and $\mathrm{H}_{4}$. 
Figure 1. ANOVA results, e-WOM ads of nostalgic products from host countries

A. Individualism Cultural Dimension of Host Countries Relative to Homeland

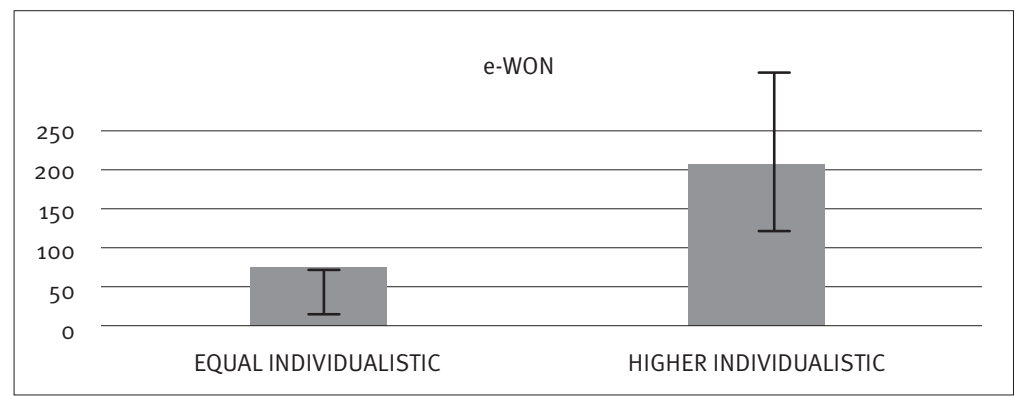

B. Masculinity Cultural Dimension of Host Countries Relative to Homeland

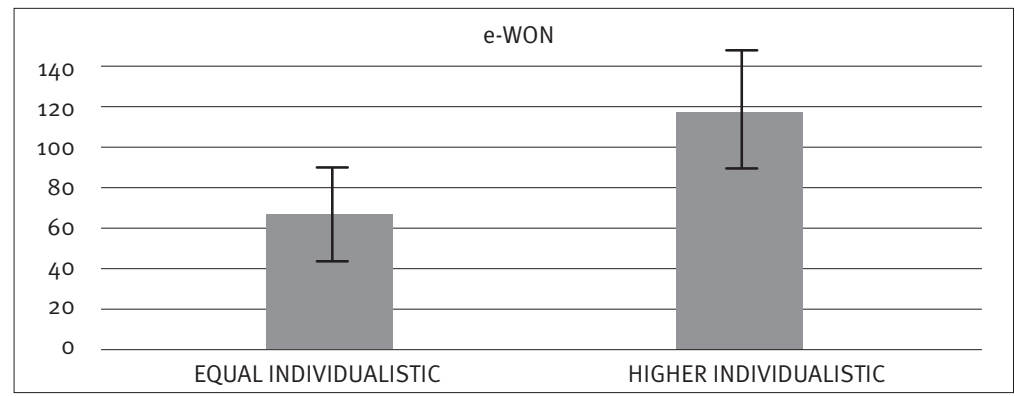

C. Economic Development Distance of Host Countries Relative to Homeland

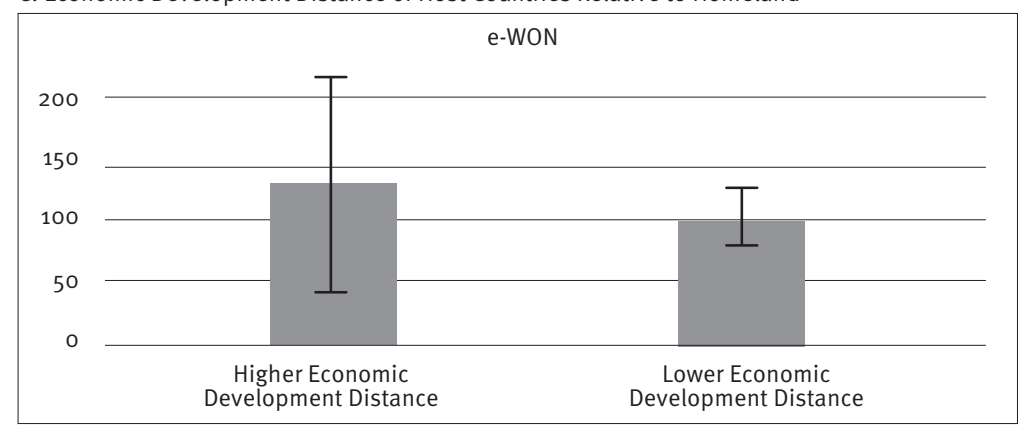

A. Individualism Cultural Dimension of Host Countries Relative to Homeland

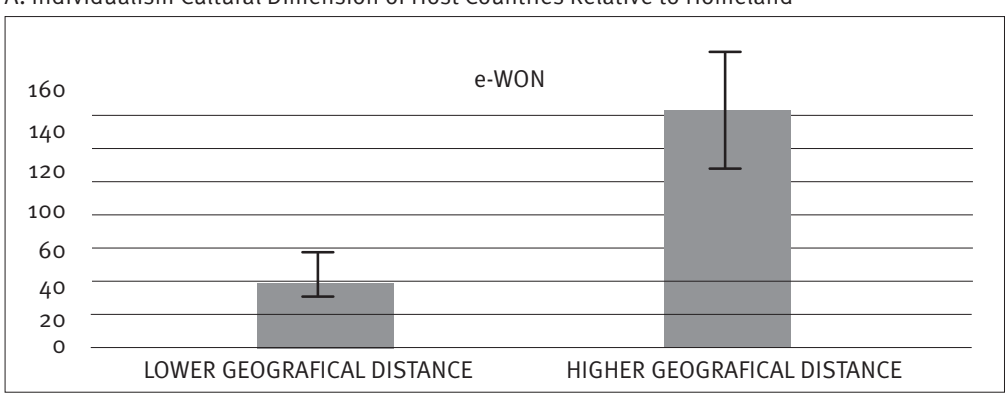

I $95 \%$ Confidence Interval. Bars with mean per condition. 
Table 4. Results: Average Treatment Effect (ATE) on population (e-WOM effect)

\begin{tabular}{|c|c|c|c|c|c|}
\hline eWOM & Coef. & Std. error & Z & $\mathrm{p}$ & Hypotheses \\
\hline Higher Individualism vs. Equal Individualism & 70 & 27 & 2,62 & $<, 010$ & $\begin{array}{c}\mathrm{H}_{1} \\
\text { Supported }\end{array}$ \\
\hline Equal Masculinity vs. Lower Masculinity & -48 & 19 & $-2,58$ & $<, 010$ & $\begin{array}{c}\mathrm{H} 2 \\
\text { Supported }\end{array}$ \\
\hline Higher Econ. Dev. vs. Lower Econ. Dev. & -.27 & 29 &,- 01 & $>, 10$ & $\begin{array}{c}\mathrm{H}_{3} \text { Not } \\
\text { Supported }\end{array}$ \\
\hline Greater Geog. Dist. vs. Lesser Geog. Dist. & 114 & 28 & 4,02 & $<, 001$ & $\begin{array}{c}\mathrm{H}_{4} \\
\text { Supported }\end{array}$ \\
\hline
\end{tabular}

The ATE methodology can be used to interpret causal effects (Imbens \& Rubin, 2015). For the diasporas in the lower economic development host country group, estimation of the treatment effect with individualism and geographic distance as the co-variables exhibits no significant effect (ATE=-.27, z=-.01, p=.993). Hence, a causal inference for Hypothesis $\mathrm{H}_{3}$ cannot be made. As mentioned, these effects are estimated for ads for nostalgic products. For diaspora groups in host countries with a greater economic development distance (with masculinity and geographic distance as the co-variables), a significant and positive treatment effect was found (ATE=123, $z=3.11, p=.002$ ).

To evaluate design validity, Gliner, Morgan, and Leech's (2011) recommendations were followed. First, a database and all data available were used. There was no observer, no observer bias, common method bias, or sample bias present. Second, the independent variables of culture and geographic distance were stable over time: no external change impacted these variables. Third, the robust results of two estimation methods (ANOVA and Welch's t-test) gave the study precedence confirmation. Fourth, the matching procedure allows for a causal interpretation instead of the mere observation of an association, without an endogenesis concern (Imbens \& Rubin, 2015).

Fifth, the measurements are used, in a similar nomological context, supported by high-quality literature that provides the overall internal design with good internal validity. Finally, because the study covered five countries, it provided adequate external validity that exceeded that of previous research on the topic.

\section{DISCUSSION}

This research proves that, as CLT predicted, social distance favors immigrants' preference for products originating in the home country due to nostalgia. This contrasts with the results of previous studies, which only referred to brands being positioned as "nostalgic", but not necessarily associated with the home country (Heinberg et al., 2019). Similarly, the results show the host country's spatial distance from the homeland influences the diaspora's preference for products from its country of origin. According to the literature review and as far as can be told, no previous research has covered this topic. These results are significant because they open up market opportunities in coming years for homeland products for diasporas and for next-generation families by taking advantage of this nostalgic appeal resulting from social and spatial distance. 


\section{CONCLUSIONS}

The results offer interesting implications for the theory on international consumer behavior because they illustrate how psychological distance drives diaspora behavior in a multicountry scenario. The findings show how cultural differences (Hofstede's individualism/collectivism and masculinity/femininity dimensions) between the homeland and the host country produce social distance for the diaspora that incentivizes them to purchase nostalgic products. Using CLT, these cultural dimensions explain the influence of culture on the development of psychological distance. Prior literature, in contrast, focused mostly on how language differences created stress among diasporas. These results can be extended to include cases of intraregional migration where there are no differences in language. Venezuelan entertainment and Venezuelan food are considered to be social bonds that connect people to their homelands through nostalgia.

The results are also consistent with the CLT-based idea that geographic distance creates spatial distance. If the host country is far from the homeland, the spatial distance is greater and leads to the diaspora's consumption of more nostalgic products.

Contrary to what was argued in Hypothesis $\mathrm{H}_{3}$, the results showed that there was no preference for nostalgic products among diasporas in countries with different levels of economic development distance. This result could be because the diasporas' psychological factors are not necessarily related to the host country's economic status.

The purchase of nostalgic products and services can create demand for them that the consumer food packaging industries from the diasporas' host country can exploit, by targeting this growing segment of products and services that perhaps host country consumers might like and adopt, as well.

This research can guide the decisions of governments and international organizations for mitigating the effects of psychological distance. In fact, they could consider promoting the commercialization of homeland (in this case, Venezuelan) products to help diasporas, because migration is a social problem for the host country and a psychological one for the migrant.

Although this study contributes by elucidating diaspora behavior regarding the consumption of nostalgic products, it has its limitations. One of the limitations of this study is the online context and the use of Instagram likes as a measure. Most Venezuelan immigrants were young people, as were Instagram users in general. However, this meant that older people were not considered in the sample. It would be ideal to extend this research to involve the offline diaspora community.

Second, as Hofstede (2019) states, using cultural dimensions in an analysis "does not imply that everyone in a given society is programmed in the same way" (p. 6). As such, an examination of how the host country culture influences individual culture is a fruitful avenue for research.

As traditional literature argues, another limitation of the study is that diaspora acculturation is a process that has different psychological stages (Brown, 1980). These stages can influence diaspora consumption patterns. However, as the Venezuelan sample is a relatively new migrant community, it can be assumed that most of them are newcomers. Studying the difference in time according to the CLT could be fruitful, starting with psychological time distance (Liberman et al., 2007).

To conclude, this literature review helps distinguish between the general topic of diaspora and the more specific topic of diaspora marketing. As such, it may act as a starting point for marketing researchers to examine new ideas for future work in this emerging field of research. 


\section{REFERENCES}

Artal-Tur, A., Ghoneim, A. F., \& Peridy, N. (2015). Proximity, trade and ethnic networks of migrants: Case study for France and Egypt. International Journal of Manpower, 36(4), 619-648. doi: 10.1108/JJM-02-2014-0062

Badinella, C., \& Chong, D. (2015). Contemporary Afro and two-sidedness: Black diaspora aesthetic practices and the art market. Culture and Organization, 21(2), 97-125. doi: $10.1080 / 14759551.2013 .806507$

Brillon, C.. (2015). From local to global: Philippine broadcast networks and the Filipino diaspora. International Journal of Communication, 9, 19. Retrieved from https://ijoc.org/index. $\mathrm{php} / \mathrm{ijoc} /$ article/view/2652

Brown, H. (1980). The optimal distance model of second language acquisition. TESOL Quarterly, 14(2), 157-164. doi: $10.2307 / 3586310$

Bundas, A. (2018). Diaspora networks and the consumption of nostalgic products among Romanian migrants in Germany. Oradea Journal of Business and Economics, 3(2), 86-99. Retrieved from https://www.econstor.eu/ bitstream/10419/69357/1/733628729.pdf

Bundy, L. (2017). Expatriates go shopping: Food and shopping acculturation. International Journal of Retail \& Distribution Management, 45 (10), 1079-1094. doi: 10.1108/ IJRDM-08-2016-0127

Centre d'Études Prospectives et d'Informations Internationales (2019). Research and expertise in the world economy. Geodist. Retrieved from http://www.cepii.fr/CEPII/en/bdd_modele/ download.asp?id=6

Chandrasen, A. (2016). Sojourner consumer behaviour: The influence of nostalgia, ethnocentrism, cosmopolitanism and place attachment (Doctoral dissertation, Lancaster University, Lancaster-UK). Retrieved from: https://www.proquest.com/ openview/ae23542546af7a77f4edfgfdfe4f8aob/1?pq-origsit $\mathrm{e}=\mathrm{gscholar} \& \mathrm{cbl}=18750 \&$ diss $=y$

Choi, J., \& Yeniyurt, S. (2015). Contingency distance factors and international research and development (R\&D), marketing, and manufacturing alliance formations. International Business Review, 24(6), 1061-1071. doi: 10.1016/j.ibusrev.2015.04.007
Cross, S. N., \& Gilly, M. C. (2014). Cultural competence and cultural compensatory mechanisms in binational households. Journal of Marketing, 78(3), 121-139. doi: 10.1509/jm.11.0310

De-Juan-Vigaray, M. D., Garau-Vadell, J. B., \& Sesé, A. (2021). Acculturation, shopping acculturation, and shopping motives of international residential tourists. Tourism Management, 83 , 1-9. 104229. doi: 10.1016/j.tourman.2020.104229

Demangeot, C., Broderick, A. J., \& Craig, C. S. (2015). Multicultural marketplaces: New territory for international marketing and consumer research. International Marketing Review, 32(2), 118-140. doi: 10.1108/IMR-01-2015-0017

Dey, B., Alwi, S., Yamoah, F., Agyapong, S., Kizgin, H., \& Sarma, M. (2019). Towards a framework for understanding ethnic consumers' acculturation strategies in a multicultural environment: A food consumption perspective. International Marketing Review. 36(5), 771-804. doi: 10.1108/IMR-03-20180103

Dey, B. L., Balmer, J. M., Pandit, A., Saren, M., \& Binsardi, B. (2017). A quadripartite approach to analysing young British South Asian adults' dual cultural identity. Journal of Marketing Management, 33(9-10), 789-816. doi: $10.1080 / 0267257 X .2017 .1324896$

Elo, M., Minto-Coy, I., Silva, S. C. E., \& Zhang, X. (2020). Diaspora networks in international marketing: How do ethnic products diffuse to foreign markets? European Journal of International Management, 14(4), 693-729. doi: 10.1504/EJIM.2020.107606

Fischer, R., Vauclair, C. M., Fontaine, J. R., \& Schwartz, S. H. (2010). Are individual-level and country-level value structures different? Testing Hofstede's legacy with the Schwartz Value Survey. Journal of Cross-Cultural Psychology, 41(2), 135-151. doi: $10.1177 / 0022022109354377$

Frank, B., Abulaiti, G., \& Enkawa, T. (2012). What characterizes Chinese consumer behavior? A cross-industry analysis of the Chinese diaspora in Japan. Marketing Letters, 23(3), 683-70. doi: 10.1007/s11002-012-9171-8

Ghemawat, P. (2001). Distance still matters : The Hard Reality of Global Expansion. Harvard Business Review, 79(8), 137147. Retrieve from: https://hbr.org/2001/09/distance-stillmatters-the-hard-reality-of-global-expansion 
Gliner, J. A., Morgan, G. A., \& Leech, N. L. (2011). Research methods in applied settings: An integrated approach to design and analysis. ( $3^{\text {rd }}$ ed). New York, NY: Routledge. https://doi. org/10.4324/9781315723082

Guzmán, F., Paswan, A. K., \& Fabrize, R. O. (2017). Crossing the border: Changes in self and brands. Journal of Consumer Marketing, 34(4), 306-318. doi: 10.1108/JCM-07-2015-1483

Heinberg, M., Katsikeas, C. S., Ozkaya, H. E., \& Taube, M. (2019). How nostalgic brand positioning shapes brand equity: Differences between emerging and developed markets. Journal of the Academy of Marketing Science, 48(5), 869-890. doi: 10.1007/s11747-019-00637-x

Henthorne, T. L., Williams, A. J., \& George, B. P. (2018). Crosscultural consumer complaining behavior in service industries: A three-nation study across the African diaspora. Journal of Marketing Theory and Practice, 26(4), 431-446. doi: $10.1080 / 10696679.2018 .1488220$

Hofstede, G. (2019). The 6 dimensions of national culture. Retrieved from https://www.hofstede-insights.com/models/ national-culture

Holak, S. L. (2014). From Brighton beach to blogs: Exploring food-related nostalgia in the Russian diaspora. Consumption Markets \& Culture, 17(2), 185-207. doi: $10.1080 / 10253866.2013 .776308$

Imbens, G. W., \& Rubin, D. B. (2015). Causal inference in statistics, social, and biomedical Sciences. New York, NY: Cambridge University Press.

Kim, Y., \& Chen, S. (2016). Designing cultural products for AsianAmerican consumers: A conceptual framework. Journal of Cultural Marketing Strategy, 2(1), 51-58. Retrieved from: https:// www.researchgate.net/publication/308520884_Designing_ Cultural_Products_for_Asian-American_Consumers_A_Conceptual_Framework

Kogut, B., \& Singh, H. (1988). The effect of national culture on the choice of entry mode. Journal of International Business Studies, 19(3), 411-432. doi: 10.1057/palgrave.jibs.8490394

Krautz, C., \& Hoffmann, S. (2017). The tenure-based customer retention model: A cross-cultural validation. Journal of International Marketing, 25(3), 83-106. doi: 10.1509/ jim.16.0040
Kumar, V., \& Pansari, A. (2016). National culture, economy, and customer lifetime value: Assessing the relative impact of the drivers of customer lifetime value for a global retailer. Journal of International Marketing, 24(1), 1-21. doi: 10.1509/ jim.15.0112

Kumar, N., \& Steenkamp, J. B. E. (2013). Diaspora marketing. Harvard Business Review, 91(10), 127-131. Retrieved from: https://hbr.org/2013/10/diaspora-marketing

Leonidou, L. C., Kvasova, O., Christodoulides, P., \& Tokar, S. (2019). Personality traits, consumer animosity, and foreign product avoidance: The moderating role of individual cultural characteristics. Journal of International Marketing, 27(2), 7696. doi: $10.1177 / 1069031 X_{19834936}$

Liberman, N., Trope, Y., \& Wakslak, C. (2007). Construal level theory and consumer behavior. Journal of Consumer Psychology, 17(2), 113-117. doi: 10.1016/S1057-7408(07)70017-7

Liviatan, I., Trope, Y., \& Liberman, N. (2008). Interpersonal similarity as a social distance dimension: Implications for perceptions of others' actions. Journal of Experimental Social Psychology, 44(5), 1256-1269. doi: 10.1016/j. jesp.2008.04.007

Matejowsky, T. (2020). What's all the buzz about? Jollibee, diaspora marketing, and next-stage fast food globalization. Food and Foodways, 28(4), 274-296. doi: $10.1080 / 07409710.2020 .1826717$

Morgan, N., Pritchard, A., \& Pride, R. (2003). Marketing to the Welsh diaspora: The appeal to hiraeth and homecoming. Journal of Vacation Marketing, 9(1), 69-80. doi: $10.1177 / 135676670200900105$

Mostafa, M. M. (2018). Mining and mapping halal food consumers: A geo-located Twitter opinion polarity analysis. Journal of Food Products Marketing, 24(7), 858-879. doi: $10.1080 / 10454446.2017 .1418695$

Murdy, S., Alexander, M., \& Bryce, D. (2018). What pulls ancestral tourists 'home'? An analysis of ancestral tourist motivations. Tourism Management, 64, 13-19. doi: 10.1016/j. tourman.2017.07.011

Ogunyemi, O. (2018). Shaping the perception of African conflicts through framing: A case study of the African diasporic press in the UK. Media, War \& Conflict, 11(4), 421-433. doi: $10.1177 / 1750635218779918$ 
Oxford Dictionary (n.d.). Definition of nostalgia. Retrieved from https://www.lexico.com/en/definition/nostalgia

Palomino-Tamayo, W., Timana, J., \& Cerviño, J. (2020). The firm value and marketing intensity decision in conditions of financial constraint: A comparative study of the United States and Latin America. Journal of International Marketing, 28(3), 21-39. doi: 10.1177/1069031X20943533

Papadopoulos, N., Banna, A. E., \& Murphy, S. A. (2017). Old country passions: An international examination of country image, animosity, and affinity among ethnic consumers. Journal of International Marketing, 25(3), 61-82. doi: 10.1509/ jim.16.0077

Penaloza, L. (1994). Atravesando fronteras/border crossings: A critical ethnographic exploration of the consumer acculturation of Mexican immigrants. Journal of Consumer Research, 21(1), 32-54. doi: 10.1086/209381

Preez, E. A. du, \& Govender, L. K. (2020). Travelling to the Motherland: Relating acculturation to diaspora tourism experiences. Anatolia, 31(2), 197-210. https://doi.org/10.108 o/13032917.2020.1747220

Quinn, M., \& Devasagayam, R. (2005). Building brand community among ethnic diaspora in the USA: Strategic implications for marketers. Journal of Brand Management, 13(2), 101-114. doi: 10.1057/palgrave.bm.2540251

R4V. (2019). Coordination platform for refugees and migrants from Venezuela. Retrieved from https://r4v.info/en/ situations/platform

Reece, A. G., \& Danforth, C. M. (2017). Instagram photos reveal predictive markers of depression. EPJ Data Science, 6(1), 1-12. doi: 10.1140/epjds/s13688-017-0110-z

Rosario, A. B., Sotgiu, F., Valck, K. De, \& Bijmolt, T. H. (2016). The effect of electronic word of mouth on sales: A meta-analytic review of platform, product, and metric factors. Journal of Marketing Research, 53(3), 297-318. doi: 10.1509/jmr.14.0380

Schmeichel, M., Kerr, S., \& Linder, C. (2020). Selfies as postfeminist pedagogy: The production of traditional femininity in the US South. Gender and Education, 32(3), 363 381. doi: 10.1080/09540253.2017.1411890

Talay, M. B., Akdeniz, M. B., Obal, M., \& Townsend, J. D. (2019). Stock market reactions to new product launches in international markets: The moderating role of culture. Journal of International Marketing, 27(4), 1-18. doi: 10.1177/1069031X19874789
Talay, M. B., Townsend, J. D., \& Yeniyurt, S. (2015). Global brand architecture position and market-based performance: The moderating role of culture. Journal of International Marketing, 23(2), 55-72. doi: 10.1509/jim.13.0164

Tambiah, S. J. (2017). Transnational movements, diaspora, and multiple modernities. Daedalus, 129(1), 163-194. Retrieved from http://www.jstor.org/stable/20027619

Tien, C., \& Luan, C. J. (2015). Is the magic of the diaspora fact or fiction? A study of Taiwan's trade performance in the bamboo network. Emerging Markets Finance and Trade, 51(sup1), S234-S250. doi: 10.1080/1540496X.2014.998890

Trope, Y., Liberman, N., \& Wakslak, C. (2007). Construal levels and psychological distance: Effects on representation, prediction, evaluation, and behavior. Journal of Consumer Psychology, 17(2), 83-95. doi: 10.1016/S1057-7408(07)70013-X

Vassolo, R. S., Castro, J. O. De, \& Gomez-Mejia, L. R. (2011). Managing in Latin America: Common issues and a research agenda. Academy of Management Perspectives, 25(4), 22-36. https://doi.org/10.5465/amp.2011.0129

Vidal, E. M., \& Tjaden, J. D. (Eds.) (2018). Global migration indicators. Global Migration Data Analysis Centre (GMDAC) International Organization for Migration. Retrieved from https://publications.iom.int/system/files/pdf/global_ migration_indicators_2018.pdf

Vries, L. De, Gensler, S., \& Leeflang, P. S. H. (2012). Popularity of brand posts on brand fan pages: An investigation of the effects of social media marketing. Journal of Interactive Marketing, 26(2), 83-91. doi: 10.1016/j.intmar.2012.01.003

Wagner, K. (2018). Nostalgic photographs in the contemporary image ecology: The example of Tyrrells crisp packaging. Journal of Aesthetics \& Culture, 10(1), 1-12 doi: $10.1080 / 20004214.2017 .1421375$

Weaver, D. B., Kwek, A., \& Wang, Y. (2017). Cultural connectedness and visitor segmentation in diaspora Chinese tourism. Tourism Management, 63, 302-314. doi: 10.1016/j. tourman.2017.06.028

Yousaf, S., \& Samreen, N. (2016). Information agents and cultural differences as determinants of country's reputation and its subsequent effects on tourism prospects of a country in sustained crises: The case of Pakistan. Journal of Vacation Marketing, 22(4), 365-384. doi: 10.1177/1356766715623828

Zhao, F., Sun, J., Devasagayam, R., \& Clendenen, G. (2018). Effects of culture and financial literacy among ChineseAmericans on participating in financial services. Journal of Financial Services Marketing, 23(1), 62-75. doi: 10.1057/ S41264-018-0044-y 


\section{AUTHOR'S CONTRIBUTIONS}

Walter Palomino-Tamayo, Maria Christina Saksanian and Otto Regalado-Pezúa declare that they participated in all stages of development of the manuscript. Dr. Walter Palomino-Tamayo worked on the conceptualization and theoretical-methodological approach. The theoretical review was conducted by Dr. Maria Christina Saksanian. Data collection was coordinated by Dr. Otto Regalado-Pezúa. Data analysis included Dr. Walter PalominoTamayo. Walter Palomino-Tamayo, Maria Christina Saksanian and Otto Regalado-Pezúa worked together in the writing and final revision of the manuscript. 